\title{
A Cellulolytic Rumen Bacterium, Micromonospora ruminantium sp.nov.
}

\author{
By G. M. MAEUSZYŃSKA AND L. JANOTA-BASSALIK \\ The Institute of Genetics and Animal Breeding, Polish Academy of Sciences, \\ Jastrzębiec, 05-55I Mroków, Poland
}

(Received 2 July 1973; revised 5 November 1973)

\begin{abstract}
SUMMAR Y
A cellulolytic Micromonospora was isolated from the rumen of a sheep. The strain is related to, but not identical with, Micromonospora propionici, the cellulolytic actinomycete isolated by Hungate (1946) from the alimentary tract of a termite.
\end{abstract}

\section{INTRODUCTION}

In 1942 Hungate observed, in the rumen of a sheep, bacteria resembling morphologically the Micromonospora. In 1946 he described Micromonospora propionici as a new species of anaerobic cellulolytic bacterium isolated from the gut of a termite. According to Hungate (1966) and Prévot (1966), nine species of anaerobic cellulolytic rumen bacteria are known at present. They belong to the genera Bacteroides, Butyrivibrio, Clostridium, Ruminococcus and Cillobacterium. The taxonomic position of the new species described by Leatherwood \& Sharma (1972) is uncertain.

The aim of the present work was to isolate the cellulolytic actinomycete from the rumen of a sheep.

\section{METHODS}

Isolation. The original culture of the cellulolytic strain was isolated from the rumen of a sheep fed ad libitum on lucerne. Samples of the rumen contents were pumped through a fistula under a $\mathrm{CO}_{2}$ atmosphere into flasks kept at $39^{\circ} \mathrm{C}$, using a perforated stomach tube. The isolation procedure was performed with all precautions for maintaining anaerobic conditions: a $\mathrm{CO}_{2}$ atmosphere, rubber stoppers, and sodium dithionite $(0.0015 \%, \mathrm{w} / \mathrm{v})$ added to the rumen fluid. Tenfold dilutions of the rumen fluid in the solution of Bryant \& Robinson (196I) were used to inoculate a liquid medium containing strips of Whatman No. I chromatographic paper (Mann, I968). From the rumen fluid diluted to I p.p.m. we obtained micro-organisms digesting cellulose. They were purified by passing several times through the liquid and agar-solidified media containing cellulose.

Characterization. The bacteria were routinely cultured anaerobically at $39^{\circ} \mathrm{C}$ in the following liquid and solid media: (i) rumen fluid, cellulose medium (Mann, I968); (ii) rumen fluid medium (Bryant \& Robinson, 196I); (iii) yeast extract and tryptose, peptone medium (van Gylswyk \& Hoffman, 1970). Cultures were transferred every seven days. Grown cultures in cellulose medium were kept at $5{ }^{\circ} \mathrm{C}$.

Morphological observations were made on bacteria grown in media (i) and (ii). Stained preparations were made from cultures which were $4 \mathrm{~h}, \mathrm{I} 2 \mathrm{~h}, \mathrm{I} 8 \mathrm{~h}, \mathrm{I}$ day, 2 days, 3 days, 6 days and Io days old. The following methods were used: Gram method, Hucker and Cohn 
(Jacobs \& Gerstein, 1965); Hiss's method for staining capsules (Jacobs \& Gerstein, 1965); Scháffer and Fulton's method for staining spores (Tanner, 1944); Leifson's method for staining flagella (Harrigan \& McCance, I966; Skerman, I967).

Observations of bacteria and bacterial sections were made with a Yeolko electron microscope, with specimens prepared as follows: For metal-shadowed specimens, I drop of a washed suspension was placed on a Formvar-coated copper grid (200 mesh), air-dried, and shadowed with carbon plus palladium at an angle of $24^{\circ}$. For negatively-stained specimens, I drop of a washed suspension was mixed with I drop of phosphotungstate $(3 \% \mathrm{w} / \mathrm{v}$, $\mathrm{pH} 7 \cdot 2)$, placed on a Formvar-coated copper grid (200 mesh), and air-dried. For ultramicrotomy, the bacteria were fixed by glutaraldehyde $(4 \%, w / v)$ in phosphate buffer, and post-fixed in osmium tetraoxide ( $\mathrm{\%} \%$, w/v). Dehydration was performed by passage through a graded series of ethanol solutions and the dehydrated bacteria were embedded in Epon; blocks were polymerized at $37^{\circ} \mathrm{C}$ for $12 \mathrm{~h}$ and then at $56{ }^{\circ} \mathrm{C}$ for the next $\mathrm{I} 2 \mathrm{~h}$. Ultrathin sections were cut with an ultramicrotome (LKB, Sweden) and stained with uranyl acetate plus lead citrate.

Growth of bacteria was observed in aerobic and anaerobic conditions in media with different redox potentials, at $39 \pm 1{ }^{\circ} \mathrm{C}$. In anaerobic conditions the following observations were made: growth in medium without $\mathrm{NaHCO}_{3}$ in a nitrogen atmosphere; the effect of growth on redox potential in glucose and cellobiose media; growth in media with $\mathrm{pH}$ values of 4.0 to 9.0 (the $\mathrm{pH}$ before inoculation was adjusted with $\mathrm{NaOH}$ or with $\mathrm{HCl}$ ); growth in media with $2.5,6.5,8.5$ and $9.5 \%(\mathrm{w} / \mathrm{v}) \mathrm{NaCl}$; the production of catalase, indole (Bryant \& Doetch, I954; Skerman, 1967), acetoin (Bryant \& Small, 1956), $\mathrm{H}_{2} \mathrm{~S}$ (van Gylswyk \& Hoffman, 1970) and ammonium (Bryant \& Burkey, 1953); the production of volatile fatty acids and of lactic acid from cellulose or from cellobiose after $24 \mathrm{~h}$ growth (Skulmowski, Honory, Honory \& Szewczyk, 1969); gelatin liquefaction (Bryant \& Burkey, I953); casein hydrolysis in roll tubes (Blackburn \& Hobson, I962; Fulghum \& Moore, 1963); starch hydrolysis after I, 3 and 7 days incubation in a starch medium; carbohydrate fermentation in a nitrogen atmosphere after $24 \mathrm{~h}$ growth in media with half the usual amount of $\mathrm{NaHCO}_{3}$ and $0.5 \%(\mathrm{w} / \mathrm{v})$ of the following carbohydrates - $\mathrm{DL}(-)$ arabinose, $\mathrm{D}(+)$ xylose, $\mathrm{L}(-) \mathrm{xylose}$, glucose, galactose, fructose, sorbose, maltose, sucrose, lactose, cellobiose, trehalose, raffinose, salicin, inulin, dulcitol, mannitol and cellulose; motility in the liquid media in capillary tubes under anaerobic conditions (observed under a phase contrast microscope); motility in semi-solid agar (Bryant \& Small, 1956).

DNA isolation and purification was by the phenol method elaborated by A. Chomczyńska (1972, unpublished) at the Institute of Biochemistry and Biophysics, Polish Academy of Sciences. Sodium citrate $(0.025 \mathrm{M})$ was added to 31 of the bacterial culture in medium (iii) at the end of exponential growth. The bacteria were then centrifuged at $0{ }^{\circ} \mathrm{C}$ and washed twice with $0.1 \mathrm{M}-\mathrm{EDTA}$ plus $0.15 \mathrm{M}-\mathrm{NaCl}$ buffer, $\mathrm{pH} 8 \cdot 2$. The wet bacteria $(\mathrm{I} \cdot 9 \mathrm{~g})$ were suspended in $17 \mathrm{ml}$ of the above buffer solution, incubated $30 \mathrm{~min}$ at $37^{\circ} \mathrm{C}$ with lysozyme $\left(0 \cdot I \%\right.$, w/v), then incubated $20 \mathrm{~min}$ at $56{ }^{\circ} \mathrm{C}$ with Sarkosyl N.L.-30 $(0 \cdot 2 \%$, w/v). Protein digestion was performed with pronase $(250 \mu \mathrm{g} / \mathrm{ml})$ at $37^{\circ} \mathrm{C}$ for several hours. Deproteinization was repeated three times with a phenol at $4{ }^{\circ} \mathrm{C}(\mathrm{pH} 8.5)$ saturated with EDTA. DNA was precipitated with $96 \%(\mathrm{v} / \mathrm{v})$ ethanol: DNA threads on the glass rods were solubilized in $15 \mathrm{ml} 0.015 \mathrm{M}-\mathrm{NaCl}+0.0015 \mathrm{M}$-sodium citrate (DSC). Next day the DNA solution, with $\mathrm{I} \cdot 2 \mathrm{ml} \mathrm{I} \cdot 5 \mathrm{M}-\mathrm{NaCl}+0.15 \mathrm{M}$-sodium citrate (CSC) added, was dialysed three times in 21 $0.15 \mathrm{M}-\mathrm{NaCl}+0.015 \mathrm{M}$-sodium citrate (SSC). When the last dialysis was finished, the solution was digested for $3 \mathrm{~h}$ with ribonuclease at $37^{\circ} \mathrm{C}$ (RNase I, conc. $200 \mu \mathrm{g} / \mathrm{ml} ; \mathrm{RNase} \mathrm{T}_{1}$, conc. $20 \mu \mathrm{g} / \mathrm{ml}$ ), and with pronase ( $\mathrm{mg} / \mathrm{ml}$ ) for several hours afterwards. Then the solution was 


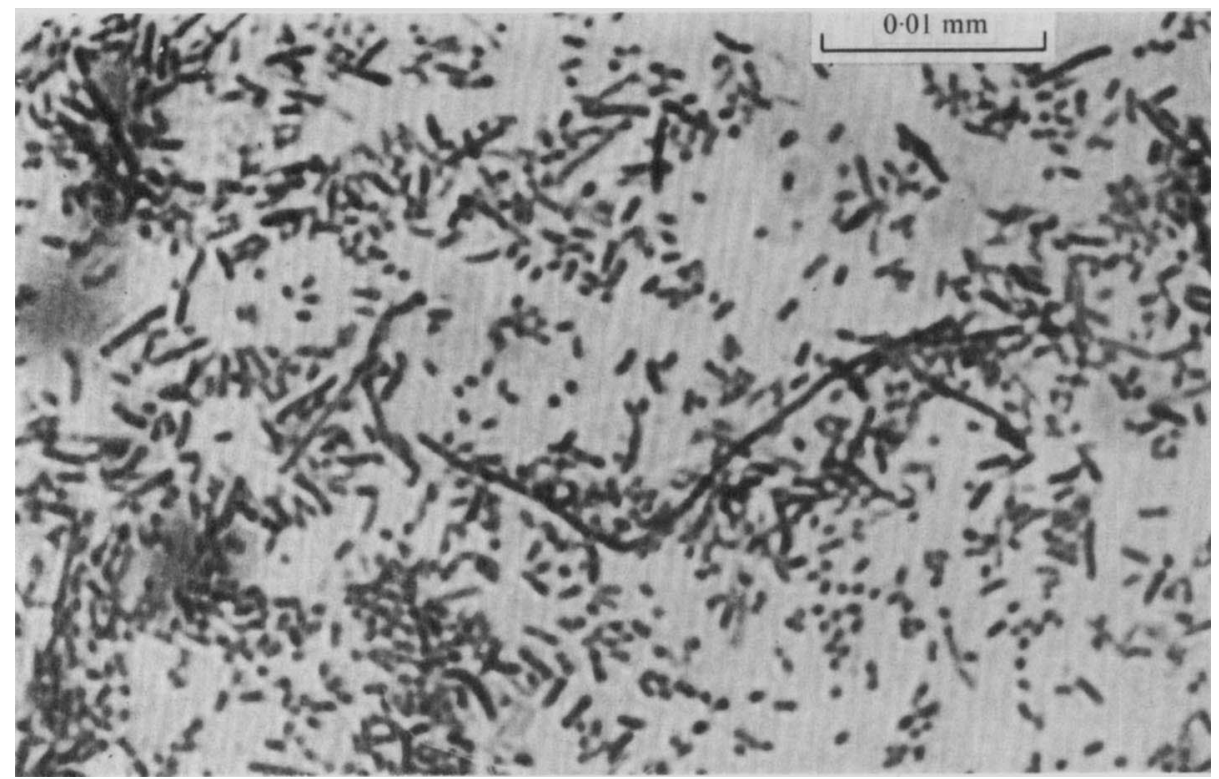

Fig. I. Micromonospora ruminantium, 24 h culture. Gram stain.

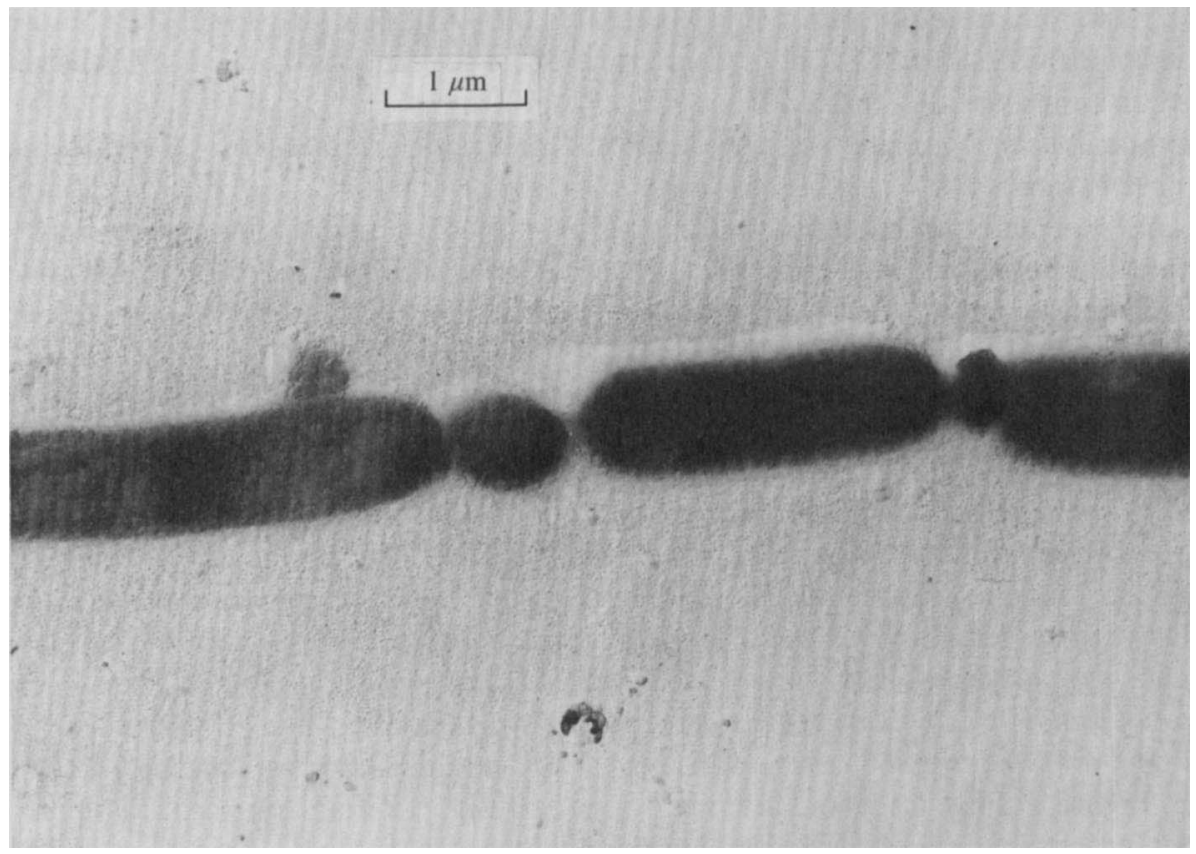

Fig. 2. Micromonospora ruminantium, $20 \mathrm{~h}$ culture. Electron micrograph, carbon-palladium shadowed, showing rods and a coccal form. 


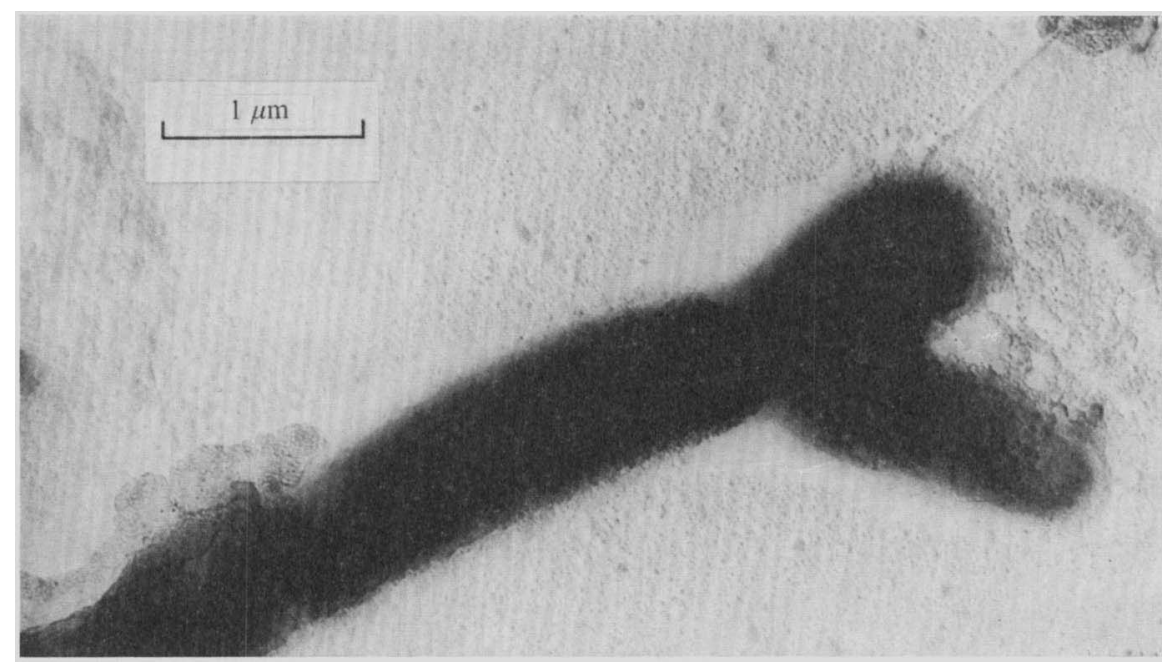

Fig. 3. Micromonospora ruminantium, $20 \mathrm{~h}$ culture. Electron micrograph, carbon-palladium shadowed, branching cell.

deproteinized three times with phenol saturated with SSC, the $\mathrm{pH}$ of the water phase being adjusted to $8 \cdot 5$, and the DNA was then precipitated with $96 \%(\mathrm{v} / \mathrm{v})$ ethanol. DNA threads on the glass rods were put into $2 \mathrm{ml}$ DSC. After the DNA had dissolved, the solution was dialysed three times in 21 SSC diluted roo times. The concentration of DNA in the solution diluted 40 times was determined from the u.v. spectrum.

The adenine and guanine content of the DNA was determined according to Huang \& Rosenberg (I966).

Redox potentials of bacterial cultures (Clark, I960; Hankus, I963) were determined using an LBS 66 potentiometer (Eureka, Warsaw) with platinum and calomel electrodes and an electrolytic bridge. The electrodes were immersed in cultures kept under a constant stream of carbon dioxide.

\section{RESULTS}

Pleomorphic, cellulolytic bacteria $\left(10^{6}\right.$ bacteria $/ \mathrm{ml}$ ) were isolated from the rumen fluid of a sheep (Fig. I). The bacteria were Gram-positive in very young cultures and later Gram-negative, and were non-motile and uncapsulated. They formed single spores at the end of the branched filaments. The spores absorbed malachite green less intensely than bacillus endospores. In pure culture, cocci, straight and curved rods, branched rods and filaments were observed. The width of cells varied from $0.33 \mu \mathrm{m}$ to $0.73 \mu \mathrm{m}$, being generally 0.4 to $0.5 \mu \mathrm{m}$. The length of the bacteria varied considerably, the shortest (coccal forms) being $0.33 \mu \mathrm{m}$ whereas rod forms were up to $3.2 \mu \mathrm{m}$ and filaments were up to $100 \mu \mathrm{m}$ in length. Figure 2 shows rods and a coccal form, and Fig. 3 a branching cell. Filaments were without cross-membranes (Fig. 4). During fission cells divided without previous crossmembrane formation (Fig. 5); this Figure also demonstrates that the wall structure is typical of that of Gram-positive bacteria.

The DNA contained $54 \cdot 5 \pm \mathrm{I} \cdot 6 \%$ GC and

$$
\frac{\mathrm{A}+\mathrm{T}}{\mathrm{G}+\mathrm{C}}=0 \cdot 84 \text {. }
$$

Surface colonies of bacteria under a carbon dioxide atmosphere were rhizoidal (Fig. 6), 


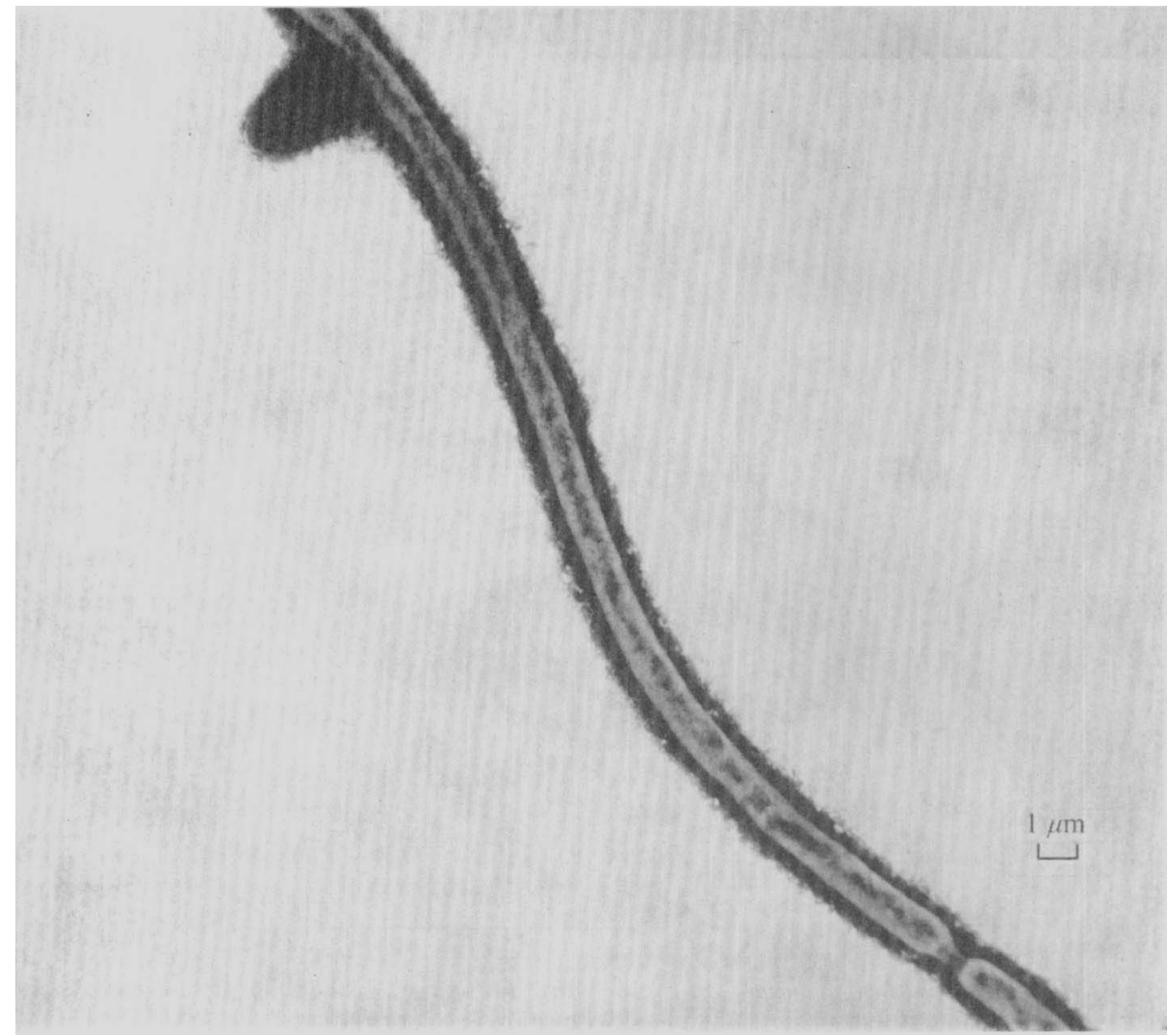

Fig. 4. Micromonospora ruminantium, $20 \mathrm{~h}$ culture. Electron micrograph, negative-stained by phosphotungstate, filament without cross membranes.

but deep agar colonies were lenticular. After $48 \mathrm{~h}$ growth the diameter of colonies was from $\mathrm{I} \cdot 2$ to $2.0 \mathrm{~mm}$. Liquid culture became uniformly turbid and then the cells sedimented. The optimal temperature for growth was $40{ }^{\circ} \mathrm{C}$. The bacteria grew at $45{ }^{\circ} \mathrm{C}$, but did not grow at $50{ }^{\circ} \mathrm{C}$. They did not grow below $\mathrm{pH} 5 \cdot 5$, or above $\mathrm{pH} 8 \cdot 0$. The maximum concentration of $\mathrm{NaCl}$ permitting growth was $4 \cdot 5 \%(\mathrm{w} / \mathrm{v})$.

The bacteria did not produce catalase and did not grow aerobically. They grew well in media with a low redox potential. The optimum growth potential, between calomel and platinum electrodes, was -350 to $-400 \mathrm{mV}$. In media without reducing agents, in which the potential before inoculation was $+60 \mathrm{mV}$, the bacteria grew very slowly, the potential decreasing after $6 \mathrm{~h}$ incubation to $-135 \mathrm{mV}$ and after $8 \mathrm{~h}$ to $-185 \mathrm{mV}$.

In $0.5 \%(\mathrm{w} / \mathrm{v})$ yeast extract and $\mathrm{I} .5 \%(\mathrm{w} / \mathrm{v})$ tryptose media the bacteria grew without rumen fluid. They fermented several carbohydrates with the production of acids. The $\mathrm{pH}$ values after three days of incubation were as follows: D-glucose 4.3 ; fructose 4.8 ; galactose $4 \cdot 6$; maltose $4 \cdot 4$; raffinose $4 \cdot 4$; cellobiose $5 \cdot 0$; salicin $5 \cdot 5$.

Acid was not produced from: $\mathrm{DL}(-)$ arabinose, $\mathrm{L}(-)$ xylose, sorbose, sucrose, lactose, trehalose, glycerol, dulcitol, $\mathrm{D}(-)$ mannitol, aesculin or inulin, the $\mathrm{pH}$ of the medium being unchanged at $6 \cdot 8$.

They hydrolysed starch, carboxymethylcellulose and cellulose (Fig. 7), and distintegration of the paper in the paper strip medium occurred within 3 days of incubation. 


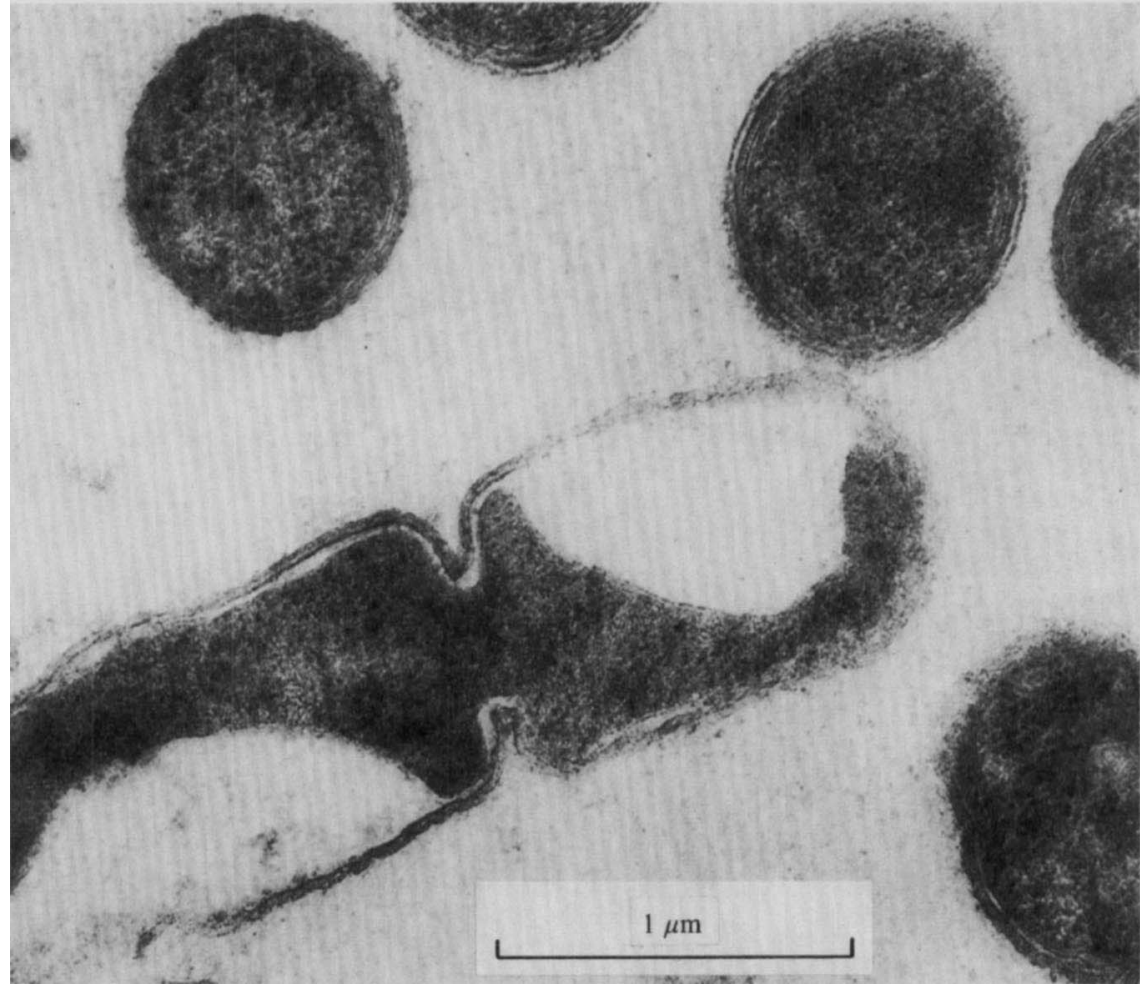

Fig. 5. Micromonospora ruminantium, 20-h-old. Ultrathin section. Fixed with glutaraldehyde and osmium tetraoxide and stained with uranyl acetate and lead citrate.

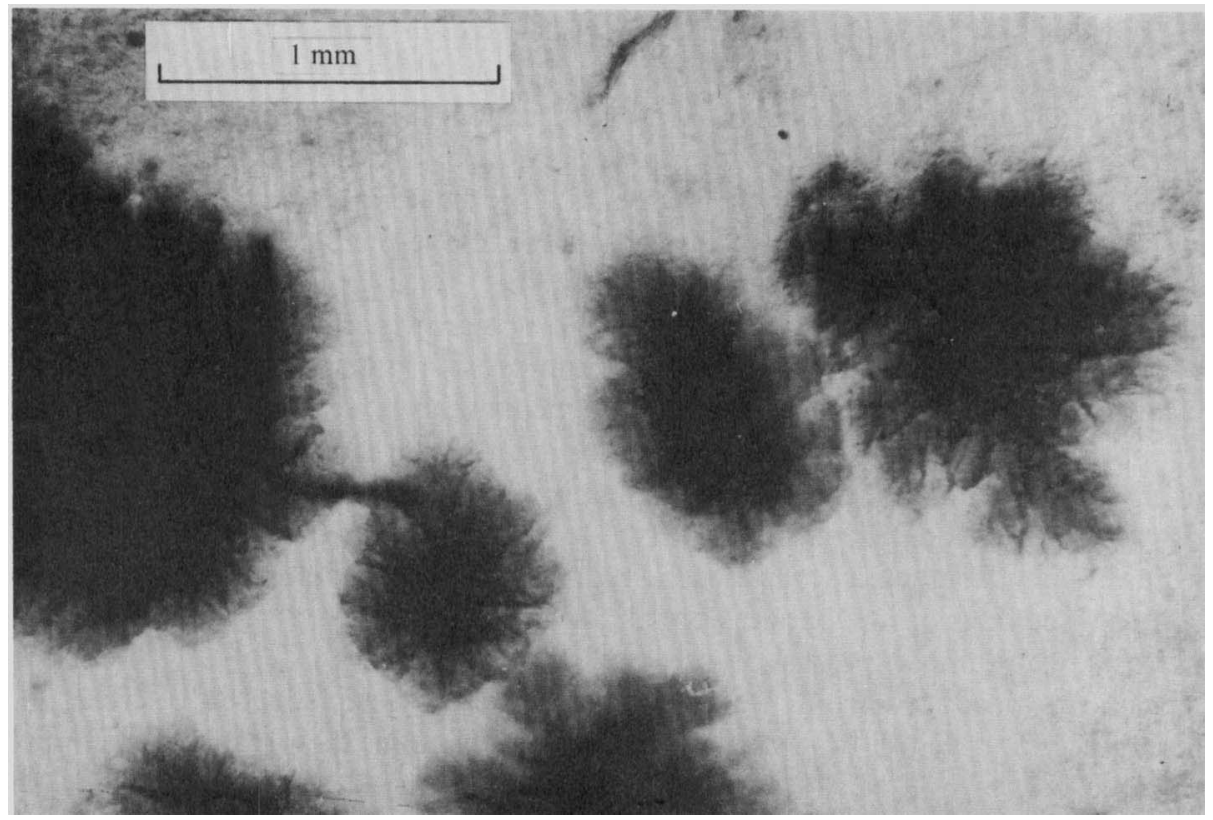

Fig. 6. Micromonospora ruminantium, 3-days-old, surface colonies (not stained) on cellobiose agar medium incubated under a constant stream of $\mathrm{CO}_{2}$. 


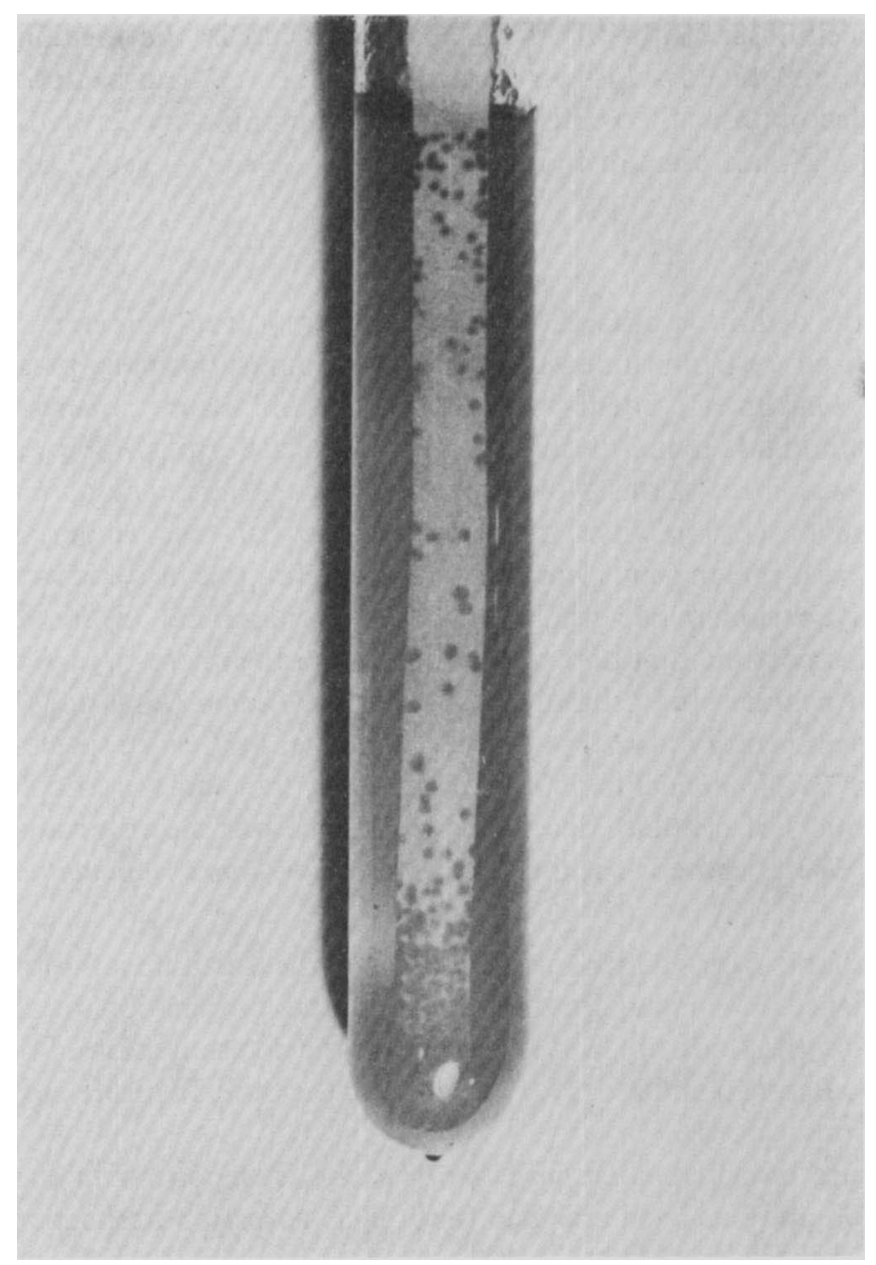

Fig. 7. Micromonospora ruminantitum, I4-days-old, zones of cellulose digestion in filter-paper strips

Table I. Acid production by Micromonospora ruminantium after $48 \mathrm{~h}$ of incubation in cellulose and in cellobiose media

\begin{tabular}{lllcc} 
& \multicolumn{4}{c}{ Acid (mmol//00 ml) } \\
Substrate & Lactic & Acetic & Propionic & Butyric \\
Cellulose & 0.774 & 0.496 & 0.143 & 0.0318 \\
Cellobiose & 0.930 & 0.606 & - & -
\end{tabular}

Valeric acid stimulated cellulolytic activity. The cellulolytic activity depended on the kind of rumen fluid used as a component of the medium. Rumen fluid from a sheep fed on lucerne gave better cellulolytic activity than rumen fluid from a sheep fed on hay. Bacteria transferred several times through yeast extract and tryptose media without rumen fluid temporarily lost cellulolytic activity, as did bacteria transferred several times through media containing only simple sugars. Cellulolytic activity was restored by 6 to 8 transfers through cellulose medium. 
Mainly lactic and acetic acids with small amounts of propionic and butyric acids were produced from cellulose. With cellobiose as a substrate in the medium without rumen fluid, only acetic and lactic acids were detected (Table I). The bacteria did not liquefy gelatin, did not decompose milk protein, produced ammonia very slowly from peptone, and did not produce $\mathrm{H}_{2} \mathrm{~S}$, acetoine, or indole.

\section{DISCUSSION}

According to the definition of Gall \& Huhtanen (195I) 'true' rumen micro-organisms are anaerobic, they produce from rumen substrates compounds normally present in the rumen, and their numbers in rumen contents are more than $10^{6} / \mathrm{ml}$. Rumen microbial species should be common to ruminants living in different geographical regions.

The bacteria described in this work, identical with Micromonospora Orskov, 1923 as described by Prévot (1966), have the characteristics of true rumen micro-organisms. Micromonospora as a rumen genus was mentioned by Hungate in 1946. van Gylswyk (1970), isolating cellulolytic rumen bacteria, found as a contaminant Gram-negative rods and filaments. It seems possible that both authors observed the micro-organisms isolated by us.

The only known anaerobic cellulolytic species of Micromonospora (M. propionici) was isolated from the alimentary tract of a termite (Hungate, 1946). The species described in this work differs from $M$. propionici in source of isolation, morphology of colonies, cellulolytic activity and products of cellulose decomposition, since our strain produces mainly lactic and acetic acids. We propose for it the name Micromonospora ruminantium.

The authors thank Mgr. A. Chomczynnska from the Institute of Biochemistry, Polish Academy of Sciences, Warsaw, for the isolation and purification of the DNA, Dr A. Płucienniczak from the Łódź Medical Academy for the determination of the GC percentage and Professor W. Brzosko and Mrs H. Pragert from the State Institute of Hygiene, Warsaw, for the photographs.

The type culture of Micromonospora ruminantium is deposited in the American Type Culture Collection and has been assigned the ATCC accession number 27728.

\section{REFERENCES}

BLACKBURN, T. H. \& Hobson, P. N. (1962). Further studies on the isolation of proteolytic bacteria from the sheep rumen. Journal of General Microbiology 29, 69-81.

BRyANT, M. P. \& BuRKeY, A. L. (1953). Cultural methods and some characteristics of some of the more numerous groups of bacteria in the bovine rumen. Journal of Dairy Science 36, 205-217.

BRYANT, M. P. \& Doetch, R. N. (1954). A study of actively cellulolytic rod shaped bacteria of the bovine rumen. Journal of Dairy Science 37, I $176-1183$.

BRyant, M. P. \& Robinson, I. M. (I96I). An improved nonselective culture medium for ruminal bacteria and its use in determining diurnal variation in number of bacteria in the rumen. Journal of Dairy Science 44, I446-1456.

BryanT, M. P. \& Small, N. (1956). The anaerobic monotrichous butyric acid producing curved rod-shaped bacteria of the rumen. Journal of Bacteriology 72, $16-21$.

Clark, W. M. (1960). Oxydation-reduction Potentials of Organic Systems. Baltimore: Williams and Wilkins.

FulGhUM, R. S. \& MOORE, W. E. C. (1963). Isolation, enumeration and characteristics of proteolytic rumen bacteria. Journal of Bacteriology 85, 806-815.

Gall, L. S. \& Huhtanen, C. N. (I95I). Criteria for judging a true rumen organism and a description of five rumen bacteria. Journal of Dairy Science 34, 353-362. 
VAN GyLSWYK, N. O. (1970). The effect of supplementing a low protein hay on the cellulolytic bacteria in the rumen of sheep and on the digestibility of cellulose and hemicellulose. Journal of Agricultural Science 74, I69-180.

van Gylswyk, N. O.\& Hoffman, J. P. L. (1970). Characteristics of cellulolytic Cillobacteria from the rumens of sheep fed teff (Eragrostics tef) hay diets. Journal of General Microbiology 6o, 38I-386.

Hankus, A. (1963). Pomiary i interpretacja potencjałów utleniająco redukujących w złożonych układach biologicznych. Zeszyty Naukowe (Wyd.) Politechnika Krakowska. No. 8 (a).

Harrigan, W. F. \& MCCANCE, M. E. (I966). Laboratory Methods in Microbiology. London \& New York: Academic Press.

Huang, P. C. \& RosenberG, E. (1966). Determination of DNA base composition via depurination. Analytical Biochemistry 16, 107-113.

Hungate, R. E. (1946). Studies on cellulose fermentation. II. An anaerobic cellulose-decomposing Actinomycete, Micromonospora propionici N.sp. Journal of Bacteriology 5r, 5I-56.

Hungate, R. E. (1966). The Rumen and its Microbes. London \& New York: Academic Press.

JACobs, B. J. \& Gerstein, M. J. W. G. (1965). Dictionary of Microbiology. London: D. van Nostrand Company I.N.C.

LEATHERWOOD, J. M. \& SHARMA, M. P. (1972). Novel anaerobic cellulolytic bacterium. Journal of Bacteriology Ixo, 75I-753.

MANN, S. O. (I968). An improved method for determining cellulolytic activity in anaerobic bacteria. Journal of Applied Bacteriology 31, 221-224.

PrÉvor, A. (1966). Manual for the Classification and Determination of the Anaerobic Bacteria. Philadelphia: Lea and Febiger.

SKerman, V. B. (1967). A Guide to the Identification of the Genera of Bacteria. Baltimore: Williams and Wilkins.

Skulmowski, J., Honory, K., Honory, D. \& Szewczyk, M. (1969). Metoda oznaczania lotnych kwasów thuszczowych (LKT) w kiszonce oraz treści żwacza przy użyciu chromatografii kolumnowej. Roczniki Nauk Rolniczych 92-B-1, 163-174.

TANnER, F. W. (1944). Microbiology of Foods. Press Champaoign. Illinois: Garrard. 